\title{
Título da página electrónica: Uppsala Conflict Data
}

\section{Program}

URL: http://www.pcr.uu.se/research/ucdp/

Gilberto C. Oliveira

\section{OpenEdition}

\section{Journals}

Edição electrónica

URL: http://journals.openedition.org/rccs/1807

DOI: $10.4000 /$ rccs. 1807

ISSN: 2182-7435

\section{Editora}

Centro de Estudos Sociais da Universidade de Coimbra

Edição impressa

Data de publição: 1 setembro 2010

Paginação: 159-160

ISSN: 0254-1106

\section{Refêrencia eletrónica}

Gilberto C. Oliveira, «Título da página electrónica: Uppsala Conflict Data Program », Revista Crítica de Ciências Sociais [Online], 90 | 2010, posto online no dia 01 outubro 2012, consultado o 22 setembro 2020. URL : http://journals.openedition.org/rccs/1807 ; DOI : https://doi.org/10.4000/rccs. 1807 


\section{Espaço Virtual}

\section{Título da página electrónica: The Communication Initiative Network URL: http://www.comminit.com/}

\begin{abstract}
A Communication Initiative Network é uma plataforma electrónica, apoiada por diversas instituições internacionais (UNDP, FAO, BBC, entre outras), que tem como objectivo aproximar e promover a partilha de experiências e, sobretudo, de conhecimento entre todos aqueles que vêem a comunicação, quer de massas quer interpessoal, como um veículo crucial na mudança e no desenvolvimento económico e social. Para isso, disponibiliza na sua página uma ampla base de dados de recursos bibliográficos. É este o grande interesse deste portal, o qual apresenta informação organizada em torno de oito grandes temáticas: desenvolvimento infantil precoce, democracia e governação, contextos frágeis, poliomielite, VIH/SIDA, tecnologias de informação e comunicação para o desenvolvimento, desenvolvimento dos meios de comunicação social e gestão de recursos naturais. A informação é sempre apresentada numa perspectiva que atribui à comunicação uma clara centralidade, reunindo recursos tão diversificados como

na área, relatórios de organizações internacionais e/ou ONG, e ligações para fóruns de discussão. A informação dada sobre cada artigo, relatório ou página, ainda que sintética, fornece todos os elementos necessários ao visitante e facilita a discussão, abrindo, no próprio espaço da base de dados, um lugar para comentários e debate. Torna-se, assim, uma ferramenta extremamente útil para quem quer iniciar investigação na área (contribuindo os comentários para uma melhor apreciação da utilidade de cada recurso), mas também para quem se quer manter actualizado ou confrontar várias perspectivas ou análises sobre essas mesmas perspectivas. Em termos de acessibilidade linguística, a página inicial, bem como os conteúdos centrais, estão todos disponíveis em inglês. Há também algumas ligações ou páginas em português, ainda que raras. Conta ainda com uma página dedicada às experiências e contextos da América Latina que é apresentada e composta por conteúdos em espanhol.
\end{abstract} publicações electrónicas científicas e não científicas, projectos concretos relevantes
Cristina Sala e Sofia José Santos

\section{Título da página electrónica: Uppsala Conflict Data Program URL: ttp://www.pcr.uu.se/research/ucdp/}

A base de dados sobre conflitos do Departamento de Estudos para a Paz e dos Conflitos da Universidade de Uppsala (Uppsala Conflict Data Program - UCDP) regista uma ampla gama de informações sobre a violência armada organizada ocorrida ou actualmente em curso em todos os países do mundo. As informações disponíveis na página do UCDP não se restringem aos casos de guerra entre Estados ou guerras civis, mas abrangem também a violência produzida por grupos armados não estatais, tais como gangues relacionados com o crime organizado, e a violência 
unilateral produzida pelo uso da força armada por governos ou grupos formais contra civis, tal como ocorre normalmente nas ditaduras.

No que se refere às guerras interestatais e civis, o UCDP fornece informações sobre todos os conflitos desde 1946, incluindo dados como o tipo de incompatibilidade, o início do conflito, a intensidade do conflito, o número de mortes, os processos de negociação, o envolvimento de terceiros, os acordo de paz, o término da violência, as facções beligerantes, a dimensão das tropas envolvidas e a participação de facções beligerantes secundárias. Quanto aos conflitos não estatais e à violência unilateral produzida por governos contra civis, o UCDP inclui informações sobre os actores envolvidos, as fatalidades e a localização dos óbitos. Para além desses dados, o UCDP apresenta comentários sobre os esforços de prevenção, tais como as conversações e negociações desenvolvidas pelas partes e por terceiros, e sobre os acordos de paz, incluindo a disponibilização do texto completo desses acordos.

A página do UCDP, disponível em sueco e em inglês, é de fácil navegação e o acesso é feito de forma simples, sem necessidade de registo pessoal prévio. As informações podem ser acedidas, basicamente, de três maneiras: consultas aos dados directamente disponibilizados na página, utilizando o país como chave de entrada; download de diversos relatórios disponíveis em arquivo; e extracção de dados para a produção de relatórios personalizados pelo usuário, usando programas do tipo MS Excel. A página apresenta ainda uma série de recursos adicionais, tais como as definições utilizadas na base de dados, as publicações dos investigadores envolvidos no UCDP e um conjunto abrangente de gráficos sobre os conflitos armados desde 1946.

\section{Gilberto C. Oliveira}

\section{Título da página electrónica: The Children and Armed Conflict Unit URL: http://www.essex.ac.uk/armedcon/default.htm}

Esta página refere-se a um projecto desenvolvido em conjunto pela The Children's Legal Centre, uma organização não-governamental britânica, e a Universidade de Essex. O objectivo da página é tornar público o impacto dos conflitos armados sobre as crianças. Nesse sentido, são divulgadas, de forma regular e actualizada, as notícias sobre conflitos, violação dos direitos humanos e questões humanitárias que afectam as crianças em todo o mundo. Essas notícias são arquivadas desde 1999 e os casos mais relevantes são transferidos para os perfis dos países.

Os perfis dos países constituem uma das principais modalidades de consulta à página. As informações específicas de cada país incluem um comentário geral sobre os antecedentes do conflito, a evolução do conflito, as ligações com as organizações não-governamentais e as organizações governamentais internacionais, as actividades no terreno, além de comentários, relatórios e análises realizadas por organizações e jornalistas, sempre mantendo o foco sobre as questões que afectam as crianças.

Outra importante modalidade de consulta à página é por tema, sendo a questão das crianças nos conflitos apresentada por áreas específicas, tais como trabalho infantil, crianças-soldado, educação, segurança alimentar, meninas, saúde, direitos humanos, minas terrestres, minorias, justiça, refugiados e deslocados e armas leves. Neste caso, a página disponibiliza, para cada tema, um conjunto abrangente 
de leis e normas, relatórios, acordos, internacionais, bem como algumas ligaconferências, artigos, notícias e infor- ções úteis para outras páginas relaciomações específicas relativas às regiões e nadas com o problema das crianças nos países afectados pelo problema. Acresce conflitos armados.

ainda que a página apresenta um arquivo de leis, acordos e outros documentos Gilberto C. Oliveira 